\title{
Illusions and Realism in the History of Human Rights
}

\author{
IVO CERMAN
}

Review article of Frederick Schauer, The Force of Law, Cambridge, Mass. Harvard UP 2015; Allen Buchanan, The Heart of Human Rights, New York, Oxford UP 2013; Samuel Moyn, Human Rights and the Uses of History, New York, Verso 2014; Brian Tierney, Liberty and Law. The Idea of Permissive Natural Law, 1100-1800, Washington, CUA Press 2014.

There has been much talk about revisionism in the history of human rights recently. Most often this term has been associated with Samuel Moyn and his book The Last Utopia. Apart from that the label "new histories of human rights“ has also appeared in connection with two conferences taking place in the USA in 2015. ${ }^{1}$ What is new about these new histories? In his influential book Moyn rejects the triumphalism of old-style narratives about human rights and argues that real human rights did not appear until the 1970s. Before that, the noble idea had only been abused to protect national states and their sinister interest. To be honest, I do not see much difference between Moyn's alleged revisionism and the enthusiastic language of older human rights histories. The developments in "new democracies“ in Eastern Europe after 1989 and the Middle East after 2010 should have warned us that enthusiasm is a very misleading guide, and imitating the American rights-talk does not solve any of the difficult issues of a just political order in a real world. If the idea of human rights is to be of any help in maintaining democracies, it would be more appropriate to require more realism and less enthusiasm in histories of human rights. For I believe that if historiography is to make a meaningful contribution to the study of the phenomenon we call human rights, it has to turn away from illusionary approaches to realism.

\section{Three Illusions}

An investigation of human rights may be said to be based on illusions any time the researcher falls prey to one of the pitfalls of language. An „arm“ as a human limb is not the same as an „arm“ as a weapon, even though both words sound and look the same. In a similar manner, historians writing about human rights may often find themselves writing about something completely different than they intended. In case of an ,arm“, we may clear our misunderstanding by looking at the object we are speaking of; in the case of immaterial abstract expressions, such as „rights“

The workshop New Histories of Human Rights, Princeton 25. 4. 2015; the Conference Does human rights have a history?, University of Chicago 10. 4. 2015. 
and „law“, sensory perception will not help us. Due to language, we may easily go astray. The necessity to grasp the immaterial object forces us, as historians, to use metaphorical language; the necessity to tell a story forces us to approach the subject as if we were recounting a biography or describing a fight. However, when we approach the subject with the illusion that human rights are an edifice having foundations, a plant having roots, or a person having a life story, or the result of a long struggle, we may easily find ourselves describing completely irrelevant things and misguiding our readers.

One may perhaps think that human rights are like a building which must have a general philosophy of human rights as its foundations. ${ }^{2}$ Someone else might believe that the building would be more stable if it were based both on morality and law, because two columns are better than one. ${ }^{3}$ However, legal theory has already taught us that law and morality are two different normative systems and mixing them up would actually result in utter injustice.
Someone else may think that it is the task of the historians to find the moment that human rights were born, and believe they have somehow been 'there' as if they were living. ${ }^{4}$ However, human rights are not human beings or animal species; they are an instrument of law. Take for example the freedom of the press, which has become a traditional part of civil rights catalogues in democratic constitutions. It also has a moment of birth. In England censorship ended in 1695, in France freedom of the press was declared in 1789 , but further development in both countries shows that these birth-moments did not bring freedom of the press to life. In both countries the freedom of the press was restricted by various stamp and tax duties and other legal limitations. It was not until 1855 in England and 1881 in France that these limitations were cancelled. ${ }^{5}$

Lastly, most of the works which pretend to deal with human rights actually focus on the fight for them. ${ }^{6}$ These are also works telling stories of injustices that

2 Examples are given below in the discussion of Allen Buchan's book.

3 This seems to be the case with Catholic critics who regret that modern human rights have lost their metaphysical foundation and seek to blend law and morality. See Alasdaire MacIntrre, After Virtue. A Study in Moral Theory, Notre Dame 1981; Jacques Maritain, Man and State, Chicago 1951; Wolfgang Wald stein, Ins Herz geschrieben. Das Naturrecht als Fundament der menschlichen Gesellschaft, Augsburg 2010.

4 Examples are given in the sections on Samuel Moyn and Brian Tierney.

5 For France see Christophe Charle - Laurent Jean Pierre, La vie intellectuelle en France I, Paris 2016; Dominique Kalifa et alii (edd.), La civilization du journal. Histoire culturelle et littéraire de la presse française, Paris 2011; for England see Stephen Koss, The Rise and Fall of the Political Press in Britain. The Nineteenth Century, London 1981.

6 This is the case with Jonathan I. Israel. His interpretations of the origins of human rights in the radical Enlightenment and the French Revolution are based on military metaphors but they do not tell us anything about human rights themselves. 
human rights are supposed to fight or describing human rights bills and institutions as results of past victories or weapons that are supposed to help to continue the fight. ${ }^{7}$ What these narratives imply is that the guarantee for justice is the fight for human rights, but not the human rights themselves. They suggest that we do not need to bother about the legal context because human rights will somehow take effect once their enemies are defeated and human rights violators punished. Justice should then be guaranteed by a never-ending witch-hunt against human rights violators and oppressors of every kind. We may call these approaches an essentialist illusion, a biographical illusion and a military illusion.

The only way to approach the subject of human rights in a realistic manner is, in my opinion, to approach them as a part of law. By this I do not mean that research should be restricted solely to positively enacted rights, but that rights should be considered as part of the social phenomenon we call law. This social institution is also immaterial but its boundaries and properties have already been sufficiently elucidated by centuries of theoretical discussions among legal theorists. We are certainly on much firmer ground when we ask what law is than when we discuss the nature of human rights, which are still taken as being above the law or as standing between law and morality. Sometimes human rights are treated as a kind of modern religion, which makes the whole concept open to similar abuses as other religions before them. Paradoxically, the military illusion may seem to attribute a great significance to law but it takes law only as a weapon against human rights violators. Law is, however, much more than threats and punishments.

But which of the new histories of human rights are on the way towards realism? Which of them follow only the path of illusions? In what follows I should like to consider four new Anglophone books which made international impact. I will divide our investigation into four parts. In the first one I will introduce two new books that may be useful for the theoretical assumptions, then I will proceed to two recent works on the history of human rights. Part three discusses the question of (dis)continuity on the example of Brian Tierney's latest book, part four examines

This is the case with a number of books on particular cases, biographies or civil rights campaigns, so it would be futile to enumerate them. For example Micheline R. IsHay, The History of Human Rights, Berkely 2004. A number of books on UN history and international human rights may be said to be written from this perspective, which is sometimes called triumphalism. For example Paul Gordon Lauren, The Human Rights. Visions Seen, Philadelphia 1998; Louis Henkin, The Age of Rights, New York 1990; Richard FALK, Human Rights Horizons. The Pursuit of Justice in a Globalizing World, London 2000; IDEM, Achieving Rights, New York 2009. There is also a fixed pattern of works on the origin of the American Declaration of Independence, or the American Bill of Rights or histories of the French Declaration of the Rights of Man and Citizen. I do not doubt that many of these works are good in their own right, but they are often mistakenly taken for works on the history of the idea of human rights. 
the idea of new international human rights. Finally I shall discuss the benefits of a new potential cooperation between historiography and legal theory.

\section{Law and Men: Bridging the Gap}

The Force of Law, a new book by the American legal theorist Frederick Schau$\mathrm{er},{ }^{8}$ is a good starting point for our discussion as it sums up in a neat fashion the current state of opinions on the question of what is law and what are the limits of its power over individuals. More importantly, it shows how difficult it is to bridge the gap between the orders of law and real human behaviour. Why is it important for human rights? If human rights are a part of law then even their power over individuals is limited.

The actual aim of the book is to revisit the question of the role of coercion in law. This is a fundamental issue of legal theory which is closely linked to the question of the nature of law. The very first natural law theorists who sought to define the main features which distinguish law and morality as two different normative systems highlighted the entitlement to coerce as the essential feature of law. We already find these convictions in the works of Samuel Pufendorf ${ }^{9}$ and Christian Thomasius. $^{10}$

In the $18^{\text {th }}$ century the force of coercion was called into doubt by Cesare Beccaria and some French legal reformers who veered to the opposite extreme and began to dream of a society without law. ${ }^{11}$ This trend of thought was continued in the $19^{\text {th }}$ century by utopian socialists who supposed that proper moral education would make law obsolete and future societies would maintain cooperation even without law. ${ }^{12}$ Other reformers inspired by Beccaria sought to reverse the logic of

8 Frederick Schauer, The Force of Law, Cambridge, MS 2015. For responses see Christoph Bezemek - Nicoleta Ladavac (eds), The Force of Law Reaffirmed, Cham 2016.

9 Samuel Pufendorf, De jure naturae et gentium libri octo, Lund 1672, book 1, chapter 6, \$4 ; IDEM, De officio hominis et civis, Lund 1673, chapter 2, § VII.

10 Christian Thomasius, Fundamenta juris naturae et gentium, Halle-Leipzig 1718 ( $1^{\text {st }}$ edition 1705), book 1 , chapter 5 , $\S$ V. However, Thomasius speaks here generally of metus externus of which punishment (poena) is just one kind.

11 The utopian dream of a future society without law already appears in Beccaria's Dei delitti e delle pene (On Crimes and Punishment) but the idea was elaborated in the reform projects of Jacques-Pierre Brissot, who proposed that education should replace law. On Beccaria see Wolfgang Rother, La maggiore felicita possibile. Untersuchung zur Philosophie der Aufklärung in Nord- und Mittelitalien, Basel 2005; on the French reformers see John A. CAREY, Judicial Reform in France before the Revolution of 1789, Cambridge, MS 1981. But this work is not concerned too much with legal theory. I have discussed these alternatives in Ivo Cerman, Podněty prirrozeného práva, in: idem (ed.), Habsburkové 1740-1918. Vznikání občanské společnosti, Prague 2016, p. 69-90.

12 For utopian socialism there is some new French scholarship see Edgar CAstelton - Hervé Toubol (ed.), Regards sur 1848, Besançon 2015; Michèle Riot-Sarcey, Le procès de la liberté. Une bistoire souterraine du $19^{e}$ siècle en France, Paris 2016; and the contributions of the American historian Jonathan BeEcher, Victor Considerant. Grandeur et décadence du socialisme romantique, Dijon 2012 ; IDEM, Fourier. Le visionaire et son monde, Paris 1993. 
law as a normative system which punishes bad behaviour and began to ask whether it would be more effective to reward good behaviour. ${ }^{13}$ In the $19^{\text {th }}$ century law as a system of orders backed by threats of punishment was reasserted by John Austin in England and Rudolf Jhering in Germany. Unlike their English colleagues ${ }^{14}$ German legal theorists were already rejecting this notion around 1870 when Ernst Rudolf Bierling, Georg Jellinek and after them Hans Kelsen replaced this simplistic notion with more nuanced conceptions of law. ${ }^{15}$ What may come as a sort of surprise is that this campaign against a coercion-based concept of law began with the curious Imperativtheorie of Karl Binding and August Thon. ${ }^{16}$

Schauer's narrative, however, starts only with the moment when Herbert L. Hart rejected this simplistic notion in England. It was in 1961 with the appearance of Hart's epoch-making book The Concept of Law where Austin's command theory of law was criticized because it failed to see that law is a broader phenomenon than orders, prohibitions and punishments. ${ }^{17}$ The concept of law had to be stretched to include power-conferring rules. Consequently Hart proved that the narrow concept of law as the commands of the superior is not consistent with the current usage of real law, and introduced a broader concept which implied that the essential aspect of law is not the threat of sanctions but recognition by members of society. Hart's work inaugurated the era of the dominance of the „soft" understanding of law which implied that law remains law even when it renounces sanctions. ${ }^{18}$

Over time some theorists began to feel that this broad concept of law failed to explain the specificity of law and its difference from other normative systems. Schauer himself presents his book as a work which only accomplishes this revisionist development. He does not make the claim of being the pioneer reversing the tide but only a successor to recent trend, the beginings of which he dates to mid-1980s.

13 This was the case with Giacinto Dragonetti, Delle virtu e delle premi (On Virtues and Rewards), Naples 1766. After him the subject was continued by Joseph Sonnenfels in his conception of Polizey-Wissenschaft.

14 On the stagnation of legal science in England see Neil Duxbury, English Jurisprudence between Austin and Hart, Virginia Law Review 91, 2005, p. 1-91.

15 See Ernst Rudolf Bierling, Zur Kritik juristischer Grundbegriffe, vol. I, Gotha 1877, p. 139-145; Georg Jellinek, Allgemeine Staatslehre, Heidelberg 1914, p. 334-337 (1 ${ }^{\text {st }}$ edition 1900); Hans Kelsen, Hauptprobleme der Staatsrechtslehre. Entwickelt aus der Lehre vom Rechtssatze, Vienna 1911, p. 203, 219-237, 270-308. However, Jellinek himself says in the second edition of his work about Kelsen that he defends coercion as the defining feature of law. I am not so sure about the correct interpretation of Kelsen's juvenile work.

16 Karl Binding, Die Normen und ibre Übertretung, I-II, Leipzig 1872-1877; August Thon, Rechtsnorm und subjektives Recht, Weimar 1878, p. 7.

17 Herbert L. Hart, The Concept of Law, Oxford 1970 (1st edition 1961).

18 H. L. Hart, The Concept, p. 48. 
It is, however, not Schauer's intention to rehabilitate the surpassed conception of law as orders backed by sanctions. He approaches the problem with the knowledge of all the new conceptual and empirical findings about the effects of law on society. Especially the empirical experiments concerning the impact of law on human behaviour make his investigations interesting, for they show that the ability of law to compel compliance is far from granted. In other words, it cannot be taken for sure that the effect of new laws on human behaviour is guaranteed merely by issuing new legislature.

Much more is needed to bridge the gap between the letter of law and real human behaviour. In dealing with the question of why people obey laws, Schauer examines culture-specific conditions of various nations, sociological surveys or psychological experiments and media. He draws on Tom Tyler's surveys in which it was proved that the fear of punishment plays only a marginal role in explaining compliance with law. Most people simply cannot be taken for the imaginary „bad man“ who must be coerced to obedience by the threat of sanctions. Other studies concerning compliance with tax laws or daily experience with the behaviour of drivers in traffic show, however, that in both cases people do not comply with the rules voluntarily. The fear of punishment does play a certain role in their decisions. Experiments conducted by Stanley Milgram be- tween 1963 and 1974 prove, for a change, that people obey law because they tend to obey authorities. ${ }^{19}$ Only rarely does law alone produce change in people's moral and policy views. ${ }^{20}$ Most often changes in habitual attitudes are produced by media, movies or education.

At the conceptual level, Schauer concludes that it is necessary to have a narrower concept of law because otherwise the question of why people obey the law would not make sense. The effects of law would be blurred by effects of other normative systems and cultural conditions. For this reason, it is advisable to return to the view that coercion is perhaps not essential but is still a central property of law. It is the main feature which distinguishes it from other normative systems.

The main function of law is, as it seems, not to punish crimes but to coordinate behaviour in complex human societies. In this regard, Schauer's views on anthropology are fascinating. In recurrent reflections on the nature of the man for whom laws are written, Schauer concludes that people do not need to be forced to good behaviour by law. It is wrong to suppose that humans are motivated either by self-interest or by fear of punishment. However, Schauer does not subscribe to a utopian belief that people are good by nature and only society spoils them. He does believe that people often act on good intentions. The aim of law is then not so much to prevent bad people from doing

\footnotetext{
19 F. Schauer, The Force, p. 68.

20 Ibidem, p. 104.
} 
bad things, as to prevent good people from what they (wrongly) think is good. ${ }^{21}$ Even the social order does not need to be safeguarded by the threat of legal punishment, for people may voluntarily develop cooperative behavior. Schauer draws here on the game theory, especially Robert Axelrod's experiments, which demonstrated that even selfish individuals may develop cooperative behaviour. This "cooperative agreement ${ }^{\text {" } 22}$ seems to be at the root of people's obedience to law.

On balance, Schauer's very intelligent and highly informative book demonstrates that law's power over people is very limited and that it is advisable to trust their own judgment. He also demonstrates that law may produce an effect on people even without a utopian transformation of human nature. It is in stark contrast to the exaggerated expectations about the power of laws enforcing human rights which we hear today from politicians and activists.

Another unrealistic assumption of human rights historiography is the belief in the existence of the contemporary human rights theory. It happens quite often that historians follow the story of a set of particular rights because they believe that their personal choice corresponds with an uncertain contemporary human rights theory, or a generally shared understanding. of human rights. The same implicit belief is often responsible for the exclusion of certain thinkers from a history of human rights. For example German theorists of natural law are often not included in the history of human rights on the assumption that the human rights they put forward were not real or that they were even faked. Historians of norms - whether law or ethics - simply select only those thinkers or works which fit into their subjective idea of what is good. This methodological problem has been already discussed once in the German legal history when Franz Wieacker sought to cope with the challenge of Hans Georg Gadamer's hermeneutics. ${ }^{23}$ Hermeneutics makes us see that legal history may be based on a "hermeneutical circle" in which the legal historian investigates history merely to confirm his preconceived selection of "good ideas". Nowadays historians might benefit from the insightful work of the American philosopher Allen Buchanan, The Heart of Human Rights, because he makes it his goal to deny belief in the existence of such generally accepted or "folk theory“ of human rights today. ${ }^{24}$

In Buchanan's view philosophers writing about human rights tend to overestimate the significance of their discipline. A range of American philosophers, including

21 Ibidem, p. 166.

22 Ibidem, p. 82.

23 Franz Wieacker, Die Provinz der Rechtsgeschichte, in: Heinz Hübner et alii (edd.), Festschrift für Erwin Seidl zum 70. Geburtstag, Köln 1975, p. 220-230. For responses from the younger generation see Uwe Wesel, Zur Methode der Rechtsgeschichte, Kritische Justiz 7, 1974, p. 337-368.

Allen Buchanan, The Heart of Human Rights, New York 2013. 
himself (as he himself says with a great deal of self-criticism), have miscomprehended the relationship between philosophy and law because they approached the question as if the most important task were to create a philosophy of human rights while the creation of particular legal instruments for their protection were taken as a mere technical procedure in which philosophers were not interested. Buchanan believes that their conceptions were based on what he calls the Mirroring View. ${ }^{25}$ In the last twenty years there have indeed been several general philosophies of human rights produced by American philosophers such as Alan Gewirth, James Nickel, James Griffin and Carl Wellmann which may have been based on this error. ${ }^{26}$ The "mirroring view" is the belief that for every legal right there must be an antecedent corresponding moral right. According to this misconception, the task of a philosopher is to define the moral right, while jurists derive a corresponding legal instrument from this starting point.
I am afraid this is true even of the work of the historian Johannes Morsink, who wrote extensively on the philosophy of the UDHR, and many other historians who sought to extract some sort of a philosophy from human rights bills. ${ }^{27}$

Conversely, Buchanan argues that the heart of human rights is not these philosophical concepts but the international law of human rights. In other words, the relationship is reversed. The most important thing about human rights is international legal instruments because they provide universal standards for regulating the behaviour of states toward the citizens under their jurisdiction. For this reason Buchanan claims that the present book will be based on analysis of legal documents protecting human rights and the practices related to them. Unfortunately, this promise is not fulfilled. There are just two instances in the whole book when Buchanan quotes legal cases, as most of the book is conceived as a dialogue with other American philosophers and their concepts. ${ }^{28}$ Actually, we

25 A. Buchanan, The Heart, p. 22, 50. For self-criticism see p. 13.

26 Alan Gewirth, The Community of Rights, Chicago 1996; James Nickel, Making Sense of Human Rights. Philosophical Reflections on the Universal Declaration of Human Rights, Berkeley 1987; James Griffin, On Human Rights, Oxford 2008; Charles A. Beitz, The Idea of Human Rights, Oxford 2009; Carl Wellmann, The Moral Dimension of human Rights, New York 2010. Readers interested in the question of a philosophy of human rights should certainly consult also the works of German thinkers: Heiner Bielefeldt, Philosophie der Menschenrechte. Grundlagen eines weltweiten Freiheitsethos, Darmstadt 1998; Otfried HöFfe, Transzendentale Interessen: Zur Anthropologie der Menschenrechte, in: Walter Kerber (ed.), Menschenrechte und kulturelle Identität, Munich 1991, p. 15-60; IDEM, Politische Gerechtigkeit, Frankfurt am Main 1987; Robert Alexy, Theorie der Grundrechte, Frankfurt am Main 1994. Johannes Morsink, Inherent Human Rights. Philosophical roots of the Universal Declaration, Philadelphia 2009.

28 A. Buchanan, The Heart, p. 111 (several cases when international courts helped defend citizens against „security measures“ of their states) and p. 124. The Island of Palmas case (United States v. Netherlands 1928). 
could find much more useful information about the working of UN human rights treaty bodies and their cases in the manual of the Jewish-Canadian activist Anne F. Bayefsky than in this academic work..$^{29}$ It is a great pity that Buchanan does not work with the data provided by the index of cases from these UN bodies. The data are available in the Universal Human rights index, and the working and weaknesses of this system would certainly be better revealed by an analysis of these data than by playing with scholarly definitions..$^{30}$ Buchanan apparently subscribes to the idea that the main goal of human rights is to protect individuals against their own states and that therefore the main efforts must be oriented at restraining the states. Like many supporters of the „international solution“, Buchanan does not even consider the question of who would guard the guardians. ${ }^{31} \mathrm{Th}$ is, however, one of the elementary problems of any legal theory since the $19^{\text {th }}$ century. If the only problem is a proper moral supervision of the performance of the states, then NGOs are seen as bodies conducting this supervision.
Buchanan does not ask who would control the NGOs. Transparency is discussed here as the main condition for a just state, but Buchanan does not ask whether NGOs themselves are transparent in their policies.$^{32}$ Let us remark that - while there are agencies checking the fi of NGOs or checking whether they devote their efforts to their declared goals - there is so far only one institution also supervising the political performance of international NGOs. This the NGO monitor at the Bar Ilan University which had been boycotted because its cooperation with Ariel..$^{33}$ Since the EU prohibit all cooperation with any Israeli institution in the „occupied territories", the NGO monitor is actually severely restricted in its efforts, and the idea of any supervision of international NGOs is taboo.

The anti-state preconception underlying this work may also be responsible for the fact that Buchanan fails to see the limits of this system. Th UN human rights treaty system makes it possible for an individual or an organization to complain about a state, but not for a state to complain about an individual or a non-state entity. ${ }^{34}$ If we

29 Anne F. Bayefsky, How to Complain to the UN Human Rights Treaty System, New York 2002. Even though the complaint procedure was changed in 2007, this book is still useful.

See http://uhri .ohchr .org/about/Upgrade (accessed on 07/01/2017).

31 See F. Schauer, The Force, p. 75-92.

A. Buchanan, The Heart, p. 218-219.

33 Their assessments are available at http://www .ngo-monitor.org (accessed on 07/01/2017).

Non-state entities such as terrorist organizations or paramilitary groups may be investigated for the violation of article 1, para 9 of the ICCPR (security of the person) but only when someone lodges a complaint against them. Usually it should be the victim, but what to do when the victim is dead? It is not supposed that the complainer would be a state. The article 1 of the CAT defines as torture only what is committed ,with the consent or acquiescence of a public official or other person acting in an official capacity“. It implies the torturer must be a state or its official. 
are to take the rulings of these bodies as a moral compass, then we have to consider that they clearly show the state as a bad institution because they are designed solely for procedures against states. This is clearly a problem in present-day conflicts between a state and a non-state entity, such as the Gaza Strip, the Russian separatist republic in Ukraine, the Islamic state, or territories governed by terrorists in Mali and Libya. ${ }^{35}$ Buchanan seems to be quite optimistic about this burning issue of international law because he deals with the ,international legal system" as if it already supervised the performance of these non-state entities as well. ${ }^{36} \mathrm{He}$ never addresses the problems with the accountability of these non-state entities under international law. It is also regrettable that Buchanan focuses only on complaints and fails to consider the fact that the relationship between the UN bodies and states also involves peaceful monitoring. In this process states are obligated to submit to the UN treaty bodies' regular reports about their performance which are then kept on record and fact-checked. Since 2007 the UN have been conducting a universal periodic review of human rights performance of all member states.

On the whole, while this part of $\mathrm{Bu}-$ chanan's monograph may be disappointing, it must be said that his treatise offers an interesting insider's view of the debates of American philosophers. What makes his investigation valuable for historical methodology is the introductory assumption that there is no generally accepted modern theory of human rights. The existence of the contemporary theory of human rights is a myth.

In general, the academic discussion among American philosophers of human rights which Buchanan addresses looks like a polemic within a very closed world. Historians might perhaps derive more benefit from the philosophical work of a lawyer, the famous American advocate of Israel, Alan Dershowitz. In his not-sofamous book Rights from Wrongs, he proposes an experiential theory of the origin of human rights. ${ }^{37} \mathrm{He}$ rejects all externalist approaches which look for the origins of human rights in something outside the structure of humanly constructed law system (God, Nature, natural law). In his view the source of human rights is mankind's historical experience of injustice. "[...] Rights are those fundamental preferences that experience and history-especially of great injustices-have taught." 38 The source of rights is "the human ability to learn from experience and to entrench rights in our laws and in our consciousness. "39 This experiential explanation is perhaps more consistent with complex historical changes then the static philosophical constructs.

35 This problem has been addressed mainly by Israeli lawyers; see Hamas, the Gaza War and Accountability, under International Law, Jerusalem 2011.

36 A. Buchanan, The Heart, p. 98, 277.

Alan Dershowitz, Rights from Wrongs. A Secular Theory of the Origins of Rights, New York 2004.

8 Ibidem, p. 81.

39 Ibidem, p. 119. 


\section{Discontinuous histories of human rights}

Respect for the complexities of life is also a strong point of the historical method used by the American historian Brian Tierney who is most famous for research into medieval thought. He had already provided a complex account of the longrange history of human (natural) rights ${ }^{40}$ in his book The Idea of Natural Rights, published in $1997 .{ }^{41}$ His last book Liberty and Law elaborates on one of the most important aspects of the account he had given in his previous historical survey. ${ }^{42}$ The first book sparked off a minor controversy in which Tierney was accused of overrating the significance of medieval thinkers and stretching the beginnings of the "modern theory of human rights" too far into the past. ${ }^{43}$ This obsession with the correct beginnings of the idea of true human rights seems to be quite common among historians. There has been quite

40 I do not distinguish a history of „natural rights“ from a history of ,human rights“. It is wrong to assume that both terms denote different histories as implied by Samuel Moyn, Giuseppe Mazzini in (and beyond) the History of Human Rights, in: Pamela Slotte - Miia Halme-Suomitari (edd.), Revisiting the Origins of Human Rights, Cambridge 2011, p. 119-139. The idea that both phrases correspond to different concepts is a corollary of the biographical illusion. It is also incorrect to believe that „natural rights“ (and its counterparts in other languages - iura connata, droits naturels, Rechte von Natur) were used only by premodern thinkers, whereas human rights only by modern thinkers. Human rights (derechos humanos) in Spanish were used as early as the $16^{\text {th }}$ century; the phrase rights of man already appears during the American Revolution and before Thomas Paine used it in his book written under the influence of French. The term iura hominum universalia was used by the German enlightener Christian Wolff, which was rendered into German as allgemeine Rechte. Younger German authors used phrases such as Rechte der Menschbeit, Menschenrecht etc. French physiocrates used the phrase 'droits naturels de l'homme'. What is important are not these phrases and their "lives" but their function within a given legal discourse or a given legal theory. It is just necessary to beware that the term natural rights (jura naturae) may sometimes denote rights of men in the state of nature and not ,innate rights“. Yet the developments of these legal theories is a larger topic which cannot be discussed here. The terms bürgerliche Rechte, droits politiques or Grundrechte (fundamental rights) denoted rights of citizens in real states. Their popularity in the $19^{\text {th }}$ century was connected with the rejection of natural law and the old idea of a state of nature. What is again important is the different legal theory behind these terms.

41 Brian Tierney, The Idea of Natural Rights. Studies on Natural Rights, Natural Law, and Church Law 1150-1625, Cambridge 1997.

42 B. Tierney, Liberty and Law. The Idea of Permissive Natural Law, 1100-1800, Washington 2014.

B. Tierney, Natural Law and Natural Rights. Old Problem and Recent Approaches, Review of Politics 64, 2002, p. 389-406; John Finnis, Aquinas on ius and Hart on rights. A Response to Tierney, Review of Politics 64, 2002, p. 407-410; Douglas Kries, In Defense of Fortin, Review of Politics 64, 2002, p. 41-413; Michael P. Zuckert, Response to Brian Tierney, Review of Politics 64, 2002, p. 411-415; Brian Tierney, Author's Rejoinder, The Review of Politics 64, 2002, p. 416-420; S. Adam Seagrave, How Old are Modern Rights? On the Lockean Roots of Contemporary Human Rights Discourse, Journal of the History of Ideas 72, 2011, p. 305-327; Brian Tierney, Response to S. Adam Seagrave's: How Old Are Modern Rights? On the Lockean Roots of Contemporary Rights Discourse, Journal of the History of Ideas 72, 2011, p. 461-468; S. Adam SEagrave, Identity and Diversity in the History of Ideas. A Reply to Brian Tierney, Journal of the History of Ideas 73, 2012, p. 163-166. 
an impressive variety of probable beginnings. Some thinkers see them in Roman law, some in the nominalist philosophy of William Ockham, some in the conciliarist theologian Jean Gerson, some in the modern Dutch thinker Grotius, some in Hobbes and still others in John Locke. ${ }^{44}$ Tierney has been attacked by a colleague who defended the merits of John Locke. ${ }^{45}$ This is quite paradoxical, for Tierney's way of writing is characterized by his reluctance to subscribe to any version of a neat continuous story of human rights. In Liberty and Law, he emphasizes - perhaps as a response to the polemic - that the history of natural rights cannot be „written as a grand narrative of an idea slowly ripening through the ages until it reached an impressive maturity in the work of some great thinker. " ${ }^{\text {"6 }}$ In his view, each era had its own problems, to which the thinkers responded. Each era had to start - so to speak from a new beginning.

Tierney does not subscribe to investigations of isolated notions, as the German Begriffsgeschichte does. The account in each book is broken down into isolated cases, in which Tierney gives the context of the discussion to which the texts belonged. Furthermore, Tierney rarely forgets to make the reader aware of the difficult structure of medieval texts, which serve as the more immediate context in which natural rights terminology occurs. When the nature of the inquiry requires it, Tierney also supplies an analysis of the author's life and work. His narrative method is a model of the contextual approach to the history of ideas. It is also a nice example of a narrative which does not follow illusions.

It is interesting to see how Tierney copes with the question of beginnings. In Natural Rights he avoided a clear answer by starting with a criticism of the interpretations proposed by the French medievalist Michel Villey who rejected the notion that subjective rights were already present in Roman law and defended the claim that the birth-moment came with William Ockham's happy synthesis of nominalism and subjective rights. In Liberty and Law the story starts with the Stoic notion of adiaphora and the Church fathers because in this inquiry Tierney already went one step further and instead of the origins of the phrase „human rights" looked for the development of the idea that there is a broad field of actions which are neither prescribed as moral duties nor prohibited as evils, but legally permitted as something either praiseworthy or at least morally indifferent.

Tierney's own answer to the question of beginnings respects the alterity of medieval intellectual culture(s). He seems to agree with Villey's conclusion that Roman legal culture was not centred around the notion of subjective rights, even though Roman legal monuments do contain well-known definitions of jus and justitia

Tierney surveys these theories in B. Tierney, The Idea, p. 2-3, 44-45, 318-321.

B. Tierney, Liberty. 
articulated in terms of individual rights. ${ }^{47}$ He sees the shift towards an emphasis on subjective rights in the Middle Ages, but does not agree with Villey's conclusion that it was Ockham who made the decisive break-through. In fact, Tierney does not acknowledge any "great thinker" or major text which would be responsible for this shift. Instead he locates the transformation in the long "flow of texts" between 1150 and 1310 . Yet between this date and the $14^{\text {th }}$ century the notion of subjective rights was debated in many different contexts by many different social groups which makes it difficult to maintain that this early development constituted a continuous process. At the beginning, it was the experts on canon law, then the French theologians who based their comments on Peter Lombard's Sentences, and in the $13^{\text {th }}$ century it was the age of Thomas Aquinas. However, their heritage was disregarded by $14^{\text {th }}$ century figures who already had to face the Great Schism and the struggle between Ludwig of Bavaria and the Papacy. Sometime between Rufinus' comment on Gratian's Decretum (around 1160), and Joannes Monachus's Grossa aurea (around 1310) the notion of subjective right as a power (potestas, potentia, vis, facultas) and as fas established itself and occupied a central place in European legal culture. Yet we must be aware that all these painfully reconstructed debates only eluci- date the role of „rights“, but not the role of „human rights“. Medieval thinkers did not argue that these rights are innate and that they belong universally to all mankind.

Each of these periods had its own major issues and specific contexts. In Liberty and Law Tierney put even more weight on the discontinuity between these contexts. They are important if we do not want to examine only the history of the isolated phrase „natural rights“, but if we also desire to understand how it was employed in the communication processes of the era. Tierney reveals in both books the significance of the debate on Franciscan poverty, which also gave impulsion to Ockham's writings. Yet in terms of continuity he is eager to identify the links between these medieval developments and early modern thinkers. He obviously stresses the Spanish theologians of the school of Salamanca, the debate on the Indians' rights and the work of the Jesuit Francisco Suarez which already responded to the challenge posed by early modern absolute monarchy to the autonomy of the church. Another strong link between medieval traditions and modern age is the system of moral laws proposed by the German enlightener Christian Wolff. Tierney has perhaps overstated his case in claiming that "Wolff's work could thus be seen as a version of Thomistic teaching brought up-to-date for a modern readership “ ${ }^{48}$ but he is certainly right in noting

47 Institutiones 1.1. and 1.3.

48 B. Tierney, Liberty, p. 316. However, Tierney has discovered that Wolff's definition of jus as facultas agendi is borrowed from Suarez. Even though Wolff never quotes Suarez by name, this is a piece of hard evidence of continuity between these two thinkers. 
that his system of natural laws and natural rights provides the most coherent account of the mutual relationship between prescriptions, prohibitions and permissions. ${ }^{49}$ In this regard, Wolff concludes centuries of the development of an idea.

Wolff also coined the notion of „permissive natural law“ which became the subject of Tierney's last book, subtitled The Idea of Permissive Natural Law, 1100-1800. I am convinced - on the basis of my own research on $17^{\text {th }}$ and $18^{\text {th }}$ century texts on natural law - that Tierney's conclusion about the crucial importance of permission is correct, and the path he is following in his book is a step in the right direction. People who only follow the history of isolated rights or believe in the existence of a modern theory of rights which somehow moulds them into a coherent whole may not realize that the idea of subjective rights is at odds with the existence of an objective legal order. It is only when we understand rights as a broad area of what is permitted under law that they may be reconciled. Tierney investigates the uses of permissive law in both of his books, but in Liberty and Law he stretches the chronology of his investigation up to Immanuel Kant and the end of the Enlightenment.

However, I am afraid that Tierney has not noticed that the notion of permissive law in this sense fell into disrepute after Wolff. His German successors reduced law to commands backed by sanctions, whereas laws that merely permit were not real laws in their view. ${ }^{50}$ In Kant's legal philosophy Erlaubnisgesetz denoted merely the general ability of a human being to bind other humans (i.e. to be a bearer of rights). ${ }^{51}$

Tierney's impression that Kant's reasoning suffers from a tension between an old tradition and a new philosophy which led to an ,awkward antinomy“ and ,an impasse Kant sought to avoid“ is based on a misconception of Kant's moral philosophy. ${ }^{52}$ For Kant, the conjectural history of a transition from a state of nature into a civil state did not serve as a logical argument with which to explain the grounding of legal obligations. The „natural law" in Kant does not prohibit and permit the same thing at the same time, for Kant did not use the highest law (or the imperative) as the highest premise for a deduction of lower duties and rights. We should not forget that he had made the famous turn towards the subject.

In moral reasoning, the subject has to decide whether whatever he/she is doing may be used as a general law upon which everybody could act. We may illustrate it by the example of his argument against suicide in the Grundlegung zur Metaphysik

49 B. Tierney, Idea, p. 51.

50 See Gottfried Achenwall - Johann Stefan Pütter, Elementa juris naturae, Göttingen 1750, $\S 106$.

51 Wilhelm Weischedel (ed.), Imanuel Kant, Die Metaphysik der Sitten, Frankfurt am Main 1978 (= Werkausgabe 8), p. 355 .

52 B. Tierney, Liberty, p. 348-349. 
der Sitten. ${ }^{53} \mathrm{He}$ does not say that ,suicide is wrong because the highest moral law says this or that and therefore we may easily infer that killing oneself is in contradiction with the bighest natural law." This kind of argument would be circular, as if it contained correct responses to all practical questions in advance. Kant laid a greater stress on the responsibility of the subject and simply urged him to ask himself whether what he was about to do could be defended as a general natural law.

In legal reasoning, the aim of the general law was merely to prevent individuals from encroaching on each other's freedom, not to follow any moral goals. Law only coordinates the social life of people inhabiting the Earth, for the basis of law in Kant is not only the Erlaubnisgesetz, which is to be understood as the capacity of each human to bind other humans by law, but also the fact that the Earth where mankind lives is finite.

Kant was later misunderstood as a kind of deficient idealist. The experiential basis of his practical philosophy was somehow ignored by $19^{\text {th }}$ century thinkers. In law, German lawyers once again had to accommodate the tension between subjective rights and objective legal order. This question became a topical problem after the defeat of the revolution of 1848 .

\section{An International School of Human Rights?}

The natural law thinkers of the $17^{\text {th }}$ and $18^{\text {th }}$ centuries have been researched by other historians, among whom we should at least mention Knud Haakonssen, Diethelm Klippel and Frank Grunert and a number of others who have recently organized themselves into the network Natural Law $1625-1800 .{ }^{54}$ It should be noted that there has always been some reluctance to admit early modern thinkers as being a part of the history of „real“ human rights, for they have always been suspected of rather being supporters of the absolute monarchy. ${ }^{55}$ However, Samuel Moyn has recently cut the Gordian knot of nuanced interpretations and declared that the real history of human rights starts only with the "human rights revolution “ of the 1970s.

The general historical survey of this new historical conception was published in 2010 in a book with the telling title The Last Utopia. ${ }^{56}$ The title comes from Moyn's conviction that human rights are the last utopia that has been left for mankind after other utopias before them failed. It also implies that utopian dreams are a good thing. After this book, the utopian conception has recently been diffused in an

53 Wilhelm Weischedel (ed.), Imanuel Kant, Grundlegung zur Metaphysik der Sitten, Frankfurt am Main 1978 (= Werkausgabe 7), p. 52. (BA 53/54).

54 See https://www.uni-erfurt.de/projekte/natural-law-project (11/01/2017).

55 For a more recent explanation of the subordination of rigths to duties in natural law theories, see Kmnud HaAkonssen, The Moral Conservativism of Natural Rights, in: Ian Hunter - David Saunders (edd.), Natural Law and Civil Sovereignty, New York 2002, p. 27-42.

56 Samuel Moyn, The Last Utopia. Human Rights in History, Cambridge, MS 2010. 
impressive number of collective volumes and articles by Moyn and his German followers Stefan Ludwig Hoffmann and Jan Eckel. One of them is a collection of articles entitled Human Rights and the Uses of History, which will be discussed below in more detail. After this collection of articles, Moyn published another short book on Christian human rights ${ }^{57}$ which documents the earlier stage of human rights in the $20^{\text {th }}$ century. Furthermore, his voice has been echoed by German historians Stefan Ludwig Hoffmann and Jan Eckel. ${ }^{58}$ In 2012 a themed issue of Geschichte und Gesellschaft was edited by Hoffmann and devoted to the penetrating insights of Samuel Moyn. ${ }^{59}$ In 2015 the idea that real human rights were born in the 1970s was elaborated in the collective volume The Breakthrough, edited by Eckel and Moyn. ${ }^{60}$ The epoch-making significance of Moyn's insights was further praised by Stefan Ludwig Hoffmann in a theoretical article published in 2016 in Past and Present. ${ }^{61}$

To an East European reader, Moyn's works convey extremely interesting insights about the American background of the 1970s human rights campaign. I consider that even Czechoslovak sources confirm that Communist regimes per- ceived Jimmy Carter's human rights campaign as the greatest threat, greater than the Helsinki process or domestic dissident movements. Moyn's works are also a valuable source of information on current American historiography, on which he comments extensively. Of course, one may wonder whether human rights historiography really began only with Lyn Hunt and her book Inventing Human Rights (2007), as Moyn asserts. ${ }^{62}$ What would Tierney and many others think about this?

The greatest difficulty for me is Moyn's conception of human rights - to be exact, I mean the fact that he does not have any conception at all. He never explains anything about the content, composition or function of rights in law, or any of the many technical problems concerning any of the legal concepts of human rights. His work is a glaring example of an approach which is based on the biographical illusion. Paradoxically, he often uses the metaphor of birth, „death at birth“ or „stillborn child“. The claim that real human rights were not born in the 1940s, as hitherto assumed, but in the 1970s still does not tell us what was new about the new human rights. It does not matter where a historian locates the „foundational

57 Samuel Moyn, Christian Human Rights, Philadelphia 2015.

58 See S. Moyn, The Last Utopia, p. 311. One collective volume actually appeared in the same yearStefan Ludwig Hof fmann (ed.), Human Rights in the Twentieth Century, New York 2010.

Geschichte und Gesellschaft 38,2012, No 4 Neue Menschenrechtsgeschichte.

Samuel Moyn - Jan Eckel (edd.), The Breakthrough. Human Rights in the 1970s, Philadelphia 2013.

Stefan Ludwig Hoffmann, Viewooint. Human Rights and History, Past and Present 232, 2016, p. 279-310; followed by Samuel Moyn, Viewpoint. The End of Human Rights History, Past and Present 233, 2016, p. 307-322.

62 S. Moyn, Die neue Historiographie der Menschenrechte, Geschichte und Gesellschaft 2012, p. 545-570. 
moment" of human rights; what matters is that such interpretations do not tell us anything about human rights.

This is closely linked to one omission in Moyn's historical account of the 1970s. He never considers the fact that even socialist states developed their own culture of human rights. ${ }^{63}$ All the socialist states had long catalogues of (civil) rights in their constitutions which were allegedly based on a "socialist conception of human rights". This theory was intentionally elaborated by a number of legal theorists who would even seek to address Western readership in books published in English. ${ }^{64}$ This effort actually intensified after Jimmy Carter's human rights offensive. Socialist states responded with a wave of scholarly works on the "socialist conception of human rights" which were presented as more genuine than the capitalist fake rights. ${ }^{65}$ The existence of this socialist conception of human rights which was intentionally presented as an alternative to the "Western concept" changes at least the factual description of what was happening. There was not a conflict between those who endorsed human rights and those who rejected human rights; there was a conflict between different concepts of human rights; and the acknowledgement of this fact makes it clear that even historians writing on this period should address the problem of the concept of human rights which Carter and the activists defended. ${ }^{66}$ Moyn tells us only when the breakthrough happened and who were the actors.

The closest to answering the question about the new concept is the chapter The Purity of this struggle in The Last Utopia. ${ }^{67}$

63 Besides, socialist states massively influenced the drafting of key UN documents. For example, the two international conventions of 1966 no longer contain a right to private property, but they do contain a longer list of economic rights, even though some of them are rather strange from a global perspective. For example Imre Szabo, The Socialist Concept of Human Rights, Budapest 1966.

See Hermann Klenner, Marxismus und Menschenrechte. Studien zur Rechtsphiloosphie, Berlin 1982; Josef BLAноž (ed.), Социалистическая концепция прав человека [Socialist Concept of Human Rights], Moscow 1986; IDEM, Občan, jeho práva a povinnosti v současném svètě, Prague 1987.

66 Now the topic has been addressed by Ned Richardson-Little, a research fellow from the University of Exeter. Writing Human Rights into the History of State Socialism (https://imperialglobalexeter. com; 24. 3. 2014). However, his research seems to be confined to the German Democratic Republic. He has published only one contribution Ned Richardson-Little, Dictatorship and Dissent: Human Rights in East Germany in the 1970s, in: Jan Eckel - Samuel Moyn (edd.), The Breakthrough: Human Rights in the 1970s, Philadelphia 2013, p. 49-67.

67 If we look at the survey of „utopian paths" that Moyn provides in The Last Utopia as being available in the 1970s, then we see that the only thinker who seems to have produced something like a philosophy of human rights in the 1970s was the Czech philosopher Jan Patočka (p. 165). Moyn quotes here a passage from his essay What Charter 77 is and what it is not. Yet even though this appraisal is flattering to our Czech nation, it is not true. Patočka did not produce any philosophy of human rights, either new or old. He never discussed this topic systematically in his works before 1976, and the essay on Charter 77 can hardly be taken for a tract of a theory of human rights (or a tract on the function of human rights in law). It is a myth to believe that he produced anything of the kind. 
If we ask what was new about the new and true human rights that appeared in the 1970s, then Moyn's answer seems to rest on two claims. Firstly, the new human rights were real because they were international and the new NGOs made it possible to supervise the moral conduct of states. Secondly, they were real because only the activists who came in the 1970 s finally had pure hearts and, unlike their miserable predecessors, they saw human rights as a universal value. The first claim implies that the real goal of human rights is to fight against the state. The second claim reveals that Moyn's own idea of real human rights is actually based on a certain vision of human nature. In his utopia justice would not be guaranteed by law but by the morality of "nice persons" in political NGOs. If the solution to achieving a better world is to be the creation of a higher supervision above the individual states, then it suffers again from the old problem of who would guard the guardians. ${ }^{68}$ Why should we trust activists from NGOs? Why should they be a better guarantee of justice than law and state? If anyone believed that, then at least the disastrous Durban conference of 2001 should have been a warning showing that the moral goals of the international NGOs are somewhat problematic.

The book Human Rights and the Uses of History does not alter this attitude. It is a collection of articles which had been previously published in the journal The
Nation. Most of them are actually just long book reviews - to be exact, six out of the eight chapters. In spite of the promising titles, we do not learn very much about the topics discussed, for they are mainly focused on evaluating the performance of the author under review. The genre of the book review does not give Moyn the opportunity to elaborate his own opinions on these problems.

In the introduction, we find quite reasonable opinions on the function of history, but they are not followed in the book itself because Moyn still follows the lunatic utopian agenda and mostly reaffirms what had been said in The Last Utopia. In the „Epilogue“ he explains that he does not actually want realism; he holds it for a good thing when human rights are hidden behind a fog of utopian dreams because only such vague utopias can motivate people. "[...] my worry is that human rights have conformed too much to reality. The utopian challenge presented by human rights has proved so minimal that they easily became neutered, and were even invoked as excuses - for example, in wars serving other interests-for choices their original advocates did not intend. "69 On the other hand, utopian dreams may lead to disastrous consequences when utopian fighters do not respect the limits of reality. A case in point is Moyn's support for the Palestinian attempt to declare the Palestinian state unilaterally by being given the status of an observer non-member state in the United

\footnotetext{
68 F. Schauer, The Force, p. 75-92.

69 S. Moyn, Human Rights, p. 136.
} 
Nations in $2012 . .^{70}$ This was a very unfortunate idea which did not help in any way and only damaged the value of previous negotiations with Israel. Moyn wrote at that time an article, Face the Nations, in which he supported the Palestinian plan. ${ }^{71}$

What is useful is the chapter Human Rights in History, which sums up in a nutshell what was said in the previous book. We learn again that previous human rights thinkers invoked human rights to „found a nation-state of their own, not to police someone else's "72, that contemporary human rights have nothing to do with $\mathrm{Eu}-$ ropean natural law, revolution, slavery or the Holocaust, ${ }^{73}$ that Carter has merit for invoking the concept „for purposes it had never before served" ${ }^{74}$ that we once again find an absolutely uncritical assessment of NGOs and their achievements, and that human rights are somehow connected to efforts to "transcend politics“. ${ }^{75}$

Unfortunately, Moyn does not follow in this collection of essays the history of the "rights talk" in the media. However, the strongest argument in favour of his thesis of the human rights revolution in the 1970s was the statistics documenting occurrences of the phrase „human rights“ in the English and American newspapers. ${ }^{76}$ Perhaps this was what was really new about human rights in the 1970s. It had become a media format, a way to communicate complex moral assessments in an easy and economical manner. Such issues would otherwise require much more complicated expressions.

\section{Conclusion: History as a Limit on Fantasies}

History and law have profited from a reciprocal cooperation at several decisive moments in their developments. In the $17^{\text {th }}$ and $18^{\text {th }}$ centuries history helped legal science to liberate itself from the heritage of Roman law, and legal theory too certainly profited from the transition from conjectural histories which were common in works on the social contract to real histories which reconstructed the true origins and developments of law in European states. Possibly one of the most fruitful periods in legal theory was the time of the disintegration of the historical school of law in the second half of $19^{\text {th }}$ century because it was also the time of a happy symbiosis between historical research and theoretical reflections on law. People like

70 It was decided by UN General Assembly resolution 67/19 (29/11/2012).

71 Samuel Moyn, Face the Nations, www.tabletmag.com, 21. 9. 2011. In that week - on 23/9/2011 Mahmoud Abbas submitted an application for a membership of Palestine in the UN.

72 S. Moyn, Human Rights, p. 70.

73 Ibidem, p. 82.

74 Ibidem, p. 70.

75 Ibidem, p. 83.

76 S. Moyn, The Last Utopia, p. 231. In fact it actually pertained only to the New York Times and London Times. 
Georg Jellinek in Germany or Roscoe Pound in the USA combined profound knowledge of history with the ability to reflect on law in a theoretical manner.

This happy symbiosis is not to be seen in present day works on legal science or in books on the history of human rights. What may be seen in $20^{\text {th }}$ century legal theory is rather a resurrection of conjectural histories. We should recall that even Herbert L. Hart's influential book The Concept of Law was framed by a story of a fictional tyrant called Rex ${ }^{77}$ whose adventures closely resembled a simplified history of Louis XIV. Some of these conjectures would be hard to combine with historical facts about the real Louis $\mathrm{XIV}$, but past experiences have shown that normative sciences may benefit from such limitations.

History is a difficult partner for those who prefer to fantasize about utopias, or for those who simply like to draft symmetrical schemes. Yet such conflicts between my schemes, plans or dreams and hard facts or lacunae in facts help me to discover my mistakes. It is good to be limited; it is good to know the limits of human possibilities when one reflects on how people ought to act - both in moral philosophy and in legal theory. In this respect I may again recall the authority of Immanuel Kant who emphasized in his lectures on moral philosophy how futile and empty are all reflections on morals when they are not supported by the study of real human actions. ${ }^{78}$ The sources of this anthropological inquiry were to be observation, travel, and books on history.

To sum up history may be useful to law - including theories of human rights - in showing such limits of human possibilities in two areas. Firstly, it may demonstrate the limits of human nature. The fantasies about utopias and about a future peopled by human rights priests with pure hearts which we encounter in Moyn's works should not be taken as a serious option. Legal theorists actually have a long experience of reflections about the question of what is the human being for whom they project legal norms. Twentieth century theorists discussed whether they wrote laws for the „bad man“ (Hohlfeld) or the "puzzled man“ (Hart) because the question of whether they wrote laws for the "morally perfect man" had already been decided. As early as the $17^{\text {th }}$ century, lawyers rejected the fantasies of Lutheran thinkers that laws should envisage a morally perfect "homo integer", who would be as innocent as the inhabitant of Paradise. This perspective was rejected because such a vision would basically make almost every real human being a criminal. Almost every aspect of real life, every weakness or vice, would lead to criminalization and punishment. ${ }^{79}$ It was argued that real humans are

77 H. L. Hart, The Concept, p. 51-76.

78 Gerd Gerhardt (ed.), Immanuel Kant, Eine Vorlesung über Ethik, Frankfurt am Main 1990, p. 12.

79 On this discussion see Hans-Peter SchneIDer, Justitia universalis. Quellenstudie zur Geschichte des christlichen Naturrechts bei Gottfried Wilhelm Leibniz, Frankfurt am Main 1967, p. 249-250. 
weak and not all their mistakes should be considered as punishable by law. The lunatic visions of a state supervised by morally superior NGO activists are actually based on the unrealistic assumption that NGO activists have some morally different and hitherto unknown moral nature than other humans. The history of real people may help us to understand that such a vision of morally perfect humans has never materialized.

Secondly, history as a history of ideas may help us to reconstruct the development of legal discipline and illustrate the limits of possible solutions. We should not forget that even such an abstract discipline as legal theory exists in time and that even past stages of its development are still a part of it. Some problems related to human rights seem to repeat themselves throughout history. For example, one of the most pressing recurrent topics is the conflict between subjective rights and the objective legal order. It has also been identified by the American lawyer and human rights activist Mary Ann Glendon, who described it metaphorically as a relationship between words and grammar. Just as it is impossible to make a meaningful assertion with isolated words if we do not know the language, it is not possible to compose a legal order from a collection of human rights placed side by side. „Our rights talk is like a book of words and phrases without a grammar and syntax " 80 This line of thought may lead to the question of whether subjective rights are not redundant. Subjective rights put side by side do not create an objective legal order, and the objective legal order may exist and fulfil its function even without the decoration of subjective rights. But this kind of question had already been discussed by natural law thinkers in the $18^{\text {th }}$ century, as well as by German positivists after 1848 . History may help us to understand these past developments. When we get rid of i1lusions, history actually becomes necessary because human rights did not fall from heaven. They are - just like law - a human creation, and getting to know them involves studying their history.

80 Mary Ann Glandon, Rights Talk. The Impoverishment of Political Discourse, New York 1991, p. 14. 


\section{Ivo Cerman}

\section{Illusions and Realism in the History of Human Rights (Abstract)}

The author argues that historiography of human rights should turn from illusionary approaches to realism and that the only way to be realistic is to consider human rights as a part of law. He identifies three such illusions which are all caused by the difficulties of using language to discuss abstract immaterial subjects (essentialist illusion, biographical illusion, military illusion). In the second part he discusses two new American works on theory (Schauer, Buchanan) which help us to understand the properties of law as a social phenomenon. Parts three and four assess two new works on history of human rights (Tierney, Moyn). The conclusion suggests that historiography and legal theory should renew a close cooperation.

KEY WORDS:

Human rights; historiography; legal theory 